\title{
LABOR IN THE STEEL INDUSTRY-THE HUMAN SIDE OF LARGE OUTPUTS ${ }^{1}$
}

\author{
By John A. Fitch, \\ Fellow, University of Wisconsin.
}

One of the most surprising things about steel mills is their seemingly limitless possibilities. The history of steel manufacture is a history of breaking records, and no sooner has some mill performed the "greatest feat ever known" than some other mill has performed a greater one. The record outputs of thirty years ago are insignificant in comparison with the average production of the present. In the last fifteen years blast furnaces have doubled their output. The Bessemer converter output has increased as rapidly, the open-hearth furnaces have made substantial advances in recent years, while rolling mills have doubled and even trebled their tonnage since 1890 . In 1892 hoop-mills were limited by the Amalgamated Association to $45^{\circ}$ bundles of cotton ties to a turn. In Painter's Mill, Pittsburgh, the union was defeated in that year, and the plant was changed from two turns to three, the men continuing to roll 450 bundles to a turn. In 1908 , this mill was operating two turns of eleven hours each, and I,300 bundles were being produced by each shift. A blooming-mill at Duquesne that was rolling 300 to 400 tons in twelve hours in 1892 rolled 900 to 1,200 tons in the same time in 1908. One of the merchant mills at the same plant has more than doubled its output in the last five years. It was turning out 100 tons in twelve hours in 1902, and in 1908 it averaged between 250 and 300 tons. The structural mills at Homestead have doubled their output in fifteen years. A shearman at Homestead told me that while his shears handled 200 tons in twenty-four hours in I893, it is now taking care of 600 tons in the same time. In I886, the Edgar Thomson Steel Works were rolling out 600 tons

${ }^{1}$ Embodying certain results of the Pittsburgh Survey carried on by the Charities Publication Committee under the auspices of the Russell Sage Foundation. The Pittsburgh Survey will be published shortly in book form.

(307) 
of rails in twenty-four hours, ${ }^{2}$ and it was considered one of the leading mills of the world. At present mill number one at this plant has a capacity of roo tons an hour, and it averages over 2,000 tons in twenty-four.

Thus it is seen that great advances have been made in the production of steel. New machinery and improved processes have gone far toward achieving the high standard that has been reached. Along with the improved machinery there has been increased power. An ingot is handled more rapidly in the blooming-mill than it used to be, fewer passes through the rolls are necessary, for it is "broken down" more at each pass. There is greater economy of time now than in former years; rolling mills do not have to wait for hot steel as was once the case. Additional furnace capacity has been provided.

But not all of the credit of the increased output can be given to the machinery. A very great deal, how much I suppose no one could well say, is due to increased intensity of physical effort. In the hoopmills, where output has more than doubled, there is practically no change in operation over that of twenty years ago. Roll changing can be accomplished more quickly on account of the overhead crane, but this is practically the only improvement. In the sheet mills output has doubled in the last twenty years, and there has not been in that time a single important change in machinery or method.

The standard of efficiency required and maintained in the mills has grown along with the growth in the tonnage. The steel mills to-day illustrate well that part of the evolutionary theory which declares that only the fit can survive. The steel workers are a strong, sturdy set of men-they must be, for when they begin to fail they cease to be steel workers. The man of thirty-five is likely to have many a gray hair while the man of forty calls himself old, and begins to think of the day when he must go to the scrap heap. Many of the steel workers of forty and forty-five have told me that they were at their best at thirty years of age, and that by the time they were thirty-five, they had begun to feel a perceptible decline in strength. The superintendents and foremen are alert in detecting weakness of any sort, and if a man begins to fail appreciably, he may expect discharge. Four years ago it was reported that a general order had been sent from headquarters to all mills of the Carnegie

"National Labor Tribune," April 24, 1886.

(308) 
Steel Company directing the superintendents to accept no more men over forty years of age in any department, and in some departments to hire only men of thirty-five and under. $^{3}$ In the rules for its pension department, adopted January I, I9O2, the American Steel and Wire Company has this provision: "No inexperienced person over thirty-five years of age and no experienced person over fortyfive years of age shall hereafter be taken into the employ of the company." There is a provision for suspending this rule in case of "special" or "professional" services, and this would seem to indicate an expectation of physical deterioration on the part of mill workers at an age when professional men are still capable of discharging their duties. Employees sixty-five years of age who have been in the service of the company ten years or more, are retired and placed on the pension list.

By this process of eliminating the unfit a very high standard of physical efficiency is maintained, but that in itself is not sufficient to get all the results desired. A strong man is no better than a weak one, unless he uses his strength, so by methods both direct and indirect the workmen are stimulated or "speeded up" to as rapid a pace as is possible. Common laborers are usually divided into gangs of convenient size and over each gang is a foreman who is commonly referred to as the "pusher," because his main duty is to "push" the men, and urge them on to keep up to a rapid pace. Every foreman is on the alert to keep his department up to a high standard; in the skilled departments as well as the unskilled, the men are urged on by those in authority. The skilled men are paid a tonnage rate and that is an incentive to them to work for large outputs, but the foremen do not hesitate to add their influence. "Look at those stopper setters and the steel pourer," said a Bessemer blower and foreman to me as.I was watching them fill the molds with the molten steel. "They are on tonnage, and you would think that would be an incentive to them to work pretty hard, but they have to be driven just the same." A British observer, after a visit of the British Iron and Steel Institute to the United States in I890, wrote of the American steel mills, "The 'bosses' drive the men to an extent that the employers would never dream of attempting in this country. There are trade unions, ${ }^{4}$ but they do not seem to be able to protect the men in

3"Pittsburgh Dispatch," September 26, 1904. States.

"This was before the destruction of unionism in the steel mills of the United 
this respect. The bosses have the faculty of driving the men and getting the maximum of work out of them, and the men do not seem to have the inclination or the power to resist the pressure."

But there are other and more indirect methods of speeding up a crew of men. The tonnage system of wage payment has its effect; the greater the tonnage the greater the pay, but this in itself would never have called forth the speed that has been developed by other methods. A very effective way of increasing the exertions of the men seems to have been a very skilful use of the spirit of emulation. Years ago this system was in operation. When a mill exceeded the record of other mills the men who accomplished the feat were praised, their names were sometimes published in the trade journals, and the superintendents of other mills taunted their men with the disgrace of being beaten. So another mill would establish a higher record, and all the other mills would struggle to keep up. It is said that for years a piece of steel plate, cut to the shape of a huge broom, was kept suspended above the Edgar Thomson blast furnaces, at Braddock, Pennsylvania, as a symbol of their position as the champion producers of pig iron in the world-having swept all competitors aside. And the men were so proud of the distinction that they worked faithfully to retain it. I was told by a Duquesne employee that the Bessemer converter men in that mill were induced repeatedly to break their own records. The output constantly increased until finally when it reached a very high point the superintendent told the men that they had proven their ability to produce that much steel, and hereafter it would be expected of them.

So the system is recognized in the industry to-day as an established thing, fostered by the head officials of the companies. Superintendent is pitted against superintendent, foreman against foreman, mill against mill. The old record becomes obsolete when a new one is made, and a goal is placed beyond the old one to be struggled for. The Carnegie Steel Company designates two months in each year, generally May and October, as "record months." The mills are pushed during these months, everything that can possibly increase output is brought into play, and all possible obstacles are removed. Some departments are run straight through the month without stopping for a single day or night of rest. The object is to break all

James Kitson, "Contemporary Review," Vol. 59, p. 629. 
previous records for a month's work. If the men succeed they are given cigars!

From the preceding it will have been gathered that the superintendents and foremen are the most important individuals in the speeding-up system. Their activities are also encouraged by external forces. Of course, there is the element of competition for positions. If a superintendent does not "make good" he is discharged, and making good consists in getting out a large product. That is the negative side of the argument. The positive side is the system of gifts and bonuses, dispensed by the United States Steel Corporation to its loyal foremen and superintendents. The effect upon some foremen of a fat turkey sent to the home for Thanksgiving or Christmas is often surprising. Extra favors shown have a farreaching effect, too, and this is understood and acted upon. "Why anybody should complain about the United States Steel Corporation is more than I can see," said a foreman with whom I had been discussing certain phases of the prevailing discontent. "They certainly treat me fine. Why the other day the superintendent came around and asked me my address, and I know what that means. There'll be a turkey left up at my house the day before Thanksgiving." I had been sitting in his parlor, talking with the foreman and his wife, and when I rose to leave, my host offered to walk down the street with me. His wife suggested that he might see about a woman to help her clean house next day, since he was going out. "Why, what's the use?" he said, protestingly. "I'll send a laborer up from the mill and he can help you as well as not." So it was arranged, and I suppose some stalwart Slav earned his $\$ 1.98$ the next day scrubbing floors instead of wheeling pig iron.

The really important influence with the men in authority, however, is the bonus system inaugurated in 1903 by the corporation, by which loyal foremen and superintendents receive cash rewards for their activities. The plan as adopted to take effect in January, 1903, provided for the setting aside of a fund each year varying from one per cent when annual earnings are $\$ 80,000,000$ to $\$ 90,000,000$, to two and one-half per cent when earnings amount to $\$ 150,000,000$,

The largest pay in the history of Homestead steel works and the largest ever made by the Carnegie Steel Company will be distributed next Friday and Saturday among the 7,000 men employed at the Homestead steel works and its auxiliariesthe Howard axle works and the Carrie blast furnaces. This pay will aggregate $\$ 308,000$ and is larger than usual because of the records broken last month at the plant.-"Pittsburgh Post," November 13, 1907. 
this fund to be distributed among all the men charged with responsibility in managing the affairs of the corporation. ${ }^{\tau}$ What this amount would be for 1907 it is impossible to ascertain, but the earnings of the United States Steel Corporation for 1907, after deducting employees' bonus funds and other expenditures, amounted to nearly $\$ 161,000,000$, so we may be sure that the bonus fund amounted to over $\$ 4,000,000$. Just how this is divided is a matter known only to the persons directly concerned. But the system is plain. Men in authority, superintendents and foremen-those who can be used most effectively in increasing output - are given a bonus each month in addition to their regular salaries or wages, if the tonnage in their department exceeds a certain point for the month. This is a matter that is not often spoken of and it is hard to ascertain how much is distributed in this way. Foremen have told me what their salaries were and have sometimes added, "And I get a bonus if we go above a certain tonnage," but none of them has ever told me the amount of the bonus. I have a friend who is employed by companies which place large orders with the Pittsburgh mills. He inspects the orders before they are shipped, and consequently is in the mills a good deal and has a wide acquaintance among foremen. They frequently show him twenty-dollar gold pieces which they received along with their regular salary payments.

The following, regarding the bonus system, appeared in a Pittsburgh paper early in $1908:^{8}$

The statement is made that in 1907 there was paid out in this bonus proposition more than $\$ 4,000,000$, while at the same time the total dividends paid to the holders of common stock was $\$ 10,166,050$. In the last five years there has been paid out in bonuses, in round figures, about $\$ 11,375,000$.

Common stockholders complain that while this was being paid out the dividend on common stock was cut from four to two per cent.

The contention is that those in authority in the Steel Corporation are paid enough salary to incite their best work, instead of voting a bonus, which was first started five years ago, and which is now said to often reach many times the original salary of the lucky one.

Early in I903 the corporation issued a pamphlet in which it was set forth that employees would be allowed to buy stock and pay for it out of their wages. Part 2 of this pamphlet provided for a bonus to be paid to officials and others after the net earnings of the corporation should reach $\$ 80,000,000$ Should it reach this figure and not exceed $\$ 90,000,000$, one per cent, or 
$\$ 80, \infty 00$, was to be divided among certain persons selected by the finance committee. If earnings exceeded $\$ 90,000,000$ and were less than $\$ 100,000,000$, this percentage of bonus division was to be increased two-tenths of one per cent. Another two-tenths was to be added for each $\$ 10,000,000$ advance in net earnings until they might reach $\$ 140,000,000$ and not exceed $\$ 150,000,000$ when the bonus was to be 2.25 per cent, and for $\$ 150,000,000$ to $\$ 160,000,000$ net profits shown, 2.5 per cent was to be divided in bonuses among those not named. There was no provision made after the net profits should pass the $\$ 160,000,000$ limit which was reached in 1907 , and at which time the common stockholders assert, more than $\$ 4,000,000$ was passed out, while they got only two per cent on the common stock.

Not all these immense bonuses went out in casl.. It was stipulated that only one-half of a man's bonus be paid in cash the first year after he has earned it, in quarterly installments, while the other half was invested in preferred stock, to be delivered to the man having earned it at the end of five years if he were then in the employ of the corporation.

A trifle more than $\$ 1,526,000$ was the bonus distributed at the end of 1903, the first year the plan was in force. The net profits at this time were $\$ 109,171,152.35$ and the distribution was on the I.4 per cent basis.

In the sixth annual report, just out, only once does the term "employees' bonus" appear and then in the item "Administrative, selling and general expenses and employees' bonus and pension funds, $\$ 15,945,436.84$." This means since the inception of the corporation, and no separate figures are given as to the bonus fund.

No bonus was paid in 1904 , as the required $\$ 80,000,000$ in net profits was not reached. Profits that year were only $\$ 73,176,521$, almost $\$ 7,000,000$ below the low-water mark on loans. Holders of common stock were also set aside, the dividends of four per cent being passed.

They have since been resumed on a two per cent basis, but the bonus plan has been in vogue very much, according to the stockholders.

The books show that in 1905 net profits jumped to $\$ 119,787,658.43$ and under the sliding scale for bonuses those to be named by the finance committee would divide r.6 per cent of this, or close to two million dollars. The net earnings went to $\$ 156,624,273.18$ in 1906 , and the bonus takers are accused of having divided about $\$ 3,900,000$ that year.

High-water mark was reached last year, when net earnings totaled $\$ 160.964,673.72$, and the common stockholders say they have the best grounds for belief that those fortunate enough to be named by the finance committee divided not less than 2.5 per cent in addition to fat salaries.

All of these things have been factors in the marvelous growth in steel production. Emulation, record months, speeding, the bonus system-all have played their part, but it still remains to point out the greatest factor in the whole system. It was stated above that the.tonnage system of wage payments would never have been suffi- 
cient, in itself, to call out the speed that now prevails. But when the rate of payment is judiciously cut from time to time, the tonnage system becomes the most effective scheme for inducing speed that has yet been devised.

It was inevitable that the tonnage rate of pay should be reduced during the last fifteen years. If the rate of wages per ton of product had remained the same during that time, the earnings of skilled men would be very high to-day. For example, the rate paid to rollers on the II9-inch plate-mill at Homestead, in 1892 , was said to be fourteen cents per ton." The II9-inch mill has been remodelled in late years to an 84-inch mill and in 1907 the rate paid the rollers in this mill was five and one-half cents-a cut of over 60 per cent in the rate. But the tonnage had increased, and in spite of the cut in the rate, the roller was able to make $\$ 9.90$ a day in 1907 . If he had been paid at the old rate he would have received over $\$ 25$ a day. From this one example a part of the reason for the cutting of the tonnage rates becomes evident. The statement is sometimes made that in certain skilled positions workmen would receive over one hundred dollars a day if they were now being paid the same tonnage rate as obtained fifteen years ago. I think that such statements are likely to be the result of rather careless guessing. At any rate I do not know of any facts that would tend to substantiate such a theory.

While the tonnage rate has been cut to keep even with the rapid increase in the output, a careful inquiry soon reveals the fact that the reductions have often preceded the advances in output, and they have more than kept even with it. It was stated above that the rollers on the 84 -inch mill at Homestead received $\$ 9.90$ a day in 1907 , but the rollers on the II 9 -inch mill were paid $\$$ I I.84 a day in $1892 .{ }^{10}$ This is a decline of sixteen per cent since 1892 , and in other positions the reductions have amounted to over twenty per cent. It is estimated by many who are in a position to know that actual earnings of skilled workmen in the steel mills have declined twenty to fifty per cent since 1890 . But it should be noted that this statement of reduction does not apply to all departments ; in some positions wages have advanced in the last decade. The day men, that is, men who are paid by the hour or by the day, instead of by the

" "Journal of Polltical Economg," Vol. II, p. 338.

${ }^{10}$ Investigations of Homestead Strike, Miscellaneous Documents No. 335, Fiftysecond Congress, first session, p. 5 . 
ton, have had their wages advanced in recent years, while the earnings of tonnage men were declining.

This fact is significant. All workmen whose efforts have a direct, appreciable bearing on the day's output, are paid by the ton. The day men are the unskilled laborers, engineers, and others who are not able to affect the result so much by lagging or "soldiering." The skilled men occupy the strategic positions and wage cutting is the most effective thing, in connection with the other devices, for increasing the output.

Whatever a man's earnings may be, whether high or low, he adjusts himself to that basis and that becomes his minimum of comfort. The man who has had six dollars a day and is reduced to four, has a harder time getting along on that than does another man on three dollars a day, because he never has had a chance to develop four-dollar tastes. A reduction in wages means sacrifice, and the desire to get back to the old basis after a reduction is stronger than is the desire to enjoy a higher wage than the accustomed average. The steel companies have been good judges of human nature in this respect. The mere possibility of greater earnings than any yet enjoyed would never have been sufficient to rouse the men to the degree of effort desired. Only a reduction could furnish the required stimulus, for that made it necessary to struggle to reach once more the old wage which was the minimum of comfort. 